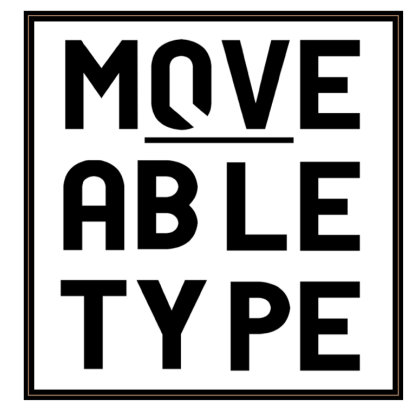

Beauty and the Beast: Rossetti's Double Victorian Lilith and Contradictory Image-

Text Relations

Author[s]: Silke Binias

Source: MoveableType, Vol. 2, 'The Mind's Eye' (2006)

DOI: $10.14324 / 111.1755-4527.015$

MoveableType is a Graduate, Peer-Reviewed Journal based in the Department of English at UCL.

(C) 2006 Silke Binias. This is an Open Access article distributed under the terms of the Creative Commons Attribution License (CC-BY) 4.0https://creativecommons.org/licenses/by/4.0/, which permits unrestricted use, distribution, and reproduction in any medium, provided the original author and source are credited.

\title{
UCLPRESS
}




\section{Beauty and the Beast: Rossetti's Double Victorian Lilith and Contradictory Text-Image Relations}

Silke Binias

\section{Lilith}

Of Adam's first wife, Lilith, it is told, (The witch he loved before the gift of Eve,)

That, ere the snake's, her sweet tongue could deceive, And her enchanted hair was the first gold.

And still she sits, young while the earth is old,

And, subtly of herself contemplative,

Draws men to watch the bright net she can weave,

Till heart and body and life are in its hold.

The rose and poppy are her flowers; for where

Is he not found, O Lilith, whom shed scent

And soft-shed kisses and soft sleep shall snare?

Lo! As that youth's eyes burned at thine, so went

Thy spell through him, and left his straight neck bent, And round his heart one strangling golden hair.

(Dante Gabriel Rossetti, Poems and Translations 146)[1]

There are two versions of Lilith by Dante Gabriel Rossetti. The oil painting Lady Lilith was begun in 1864 and was finished in 1868. The sonnet "Lilith" was written in 1867 and inscribed on the frame of Lady Lilith and was first published three years later in Rossetti's Poems (1870); when it was reprinted in the 1881 edition of The House of Life its title was changed to "Body's Beauty," thereby making it a companion poem to "Soul's Beauty."

When analysing these two, everything hinges on the text-image relations between them. Established ekphrastic interpretations are based on two premises. Firstly, they claim that Rossetti depicts Lilith as the prototypical Victorian femme fatale.

Secondly, they argue that the text describes and amplifies the fatal woman in the picture (Ainsworth 78; Miller 126; Bullen 135-37; Johnston 119). Relations between image and text are thus seen as complementary. As a consequence, the poetpainter is regarded not only as reaffirming the cliché of deadly female sexuality, but also as shaping the Victorian notion of this literary feminine image in creating a highly original type described by one critic as "the full-bodied, full-throated, longhaired ... version of lethal womanhood" (Allen Femme Fatale 6).

In contrast to this critical consensus, my analysis is based on Greimas' concept of isotopies as forming the semantic deep structure of a text (Greimas, Strukturale Semantik 15 et passim). It deals with the isotopic clash between text and image. The subject of Lady Lilith is a beautiful, highly eroticised woman combing her hair while she observes herself in a hand mirror. She is not depicted as vicious or fatal. But the 
sonnet describes Lilith from Jewish mythology and scripture, a deceitful "witch" (2) and a victimiser of men. The relations of text to image here are not complementary, but contradictory. They are based on negation: the text conveys a statement that contradicts the image. Such a view has important consequences for the conclusions feminist critics in particular have drawn about the painting and about Rossetti.

As early as 1868 , Swinburne, in his review of Lady Lilith, had drawn attention to the inoffensive nature of the painted woman, stressing that the picture does not feature Lilith as a witch: "Of evil desire or evil impulse she has nothing; and nothing of good. She is indifferent, equable, magnetic; she charms and draws down the souls of men by pure force of absorption, in no wise wilful or malignant" (212). This discrepancy between the two Lilith representations has also been noted by a number of scholars, who have attempted to explain away the antithetical relationship between image and text by reading the sonnet as a set of instructions for interpreting the picture.

Catherine Golden exemplifies this approach: "the painting," she writes, "posits in the reader a concrete graphic knowledge which strengthens and specifies the visual imagery of the sonnet." Golden makes the comparison with Rossetti's numerous other woman-and-flower pictures: these paintings "appear at first glance as portraits of beautiful women," while the sonnets attached to them "reveal the symbolism behind the feminine subjects. The sonnets give a portion of the history behind the principle figure on canvas" (Golden 395-96. See also Allen, "Strangling Golden Hair" 291; Johnston 119).

I will argue along the following lines: first, in the literary-critical tradition of psychologising the implied speakers of Victorian poems, I will read the poem as the monologue intérieur of an art spectator, and as the interpretation of a man's interpretation of a picture. Secondly, I will try to show that the question of why this spectator is incapable of perceiving feminine beauty for what it is, but demonises it instead in accordance with a traditional image of fatal femininity, is essential to Rossetti's seemingly incongruous combination of picture and text. It is also essential to the more general socio-psychological repercussions both forms of art draw attention to. I will suggest that Rossetti's double work of art explicitly displays the construction of gender stereotypes in the motif of the fatal woman precisely because his double Lilith is based on the different semantic and semiotic implications of the visual and the verbal portrait of Lilith. Following Roland Barthes' theory of myths, I view the text as presenting culturally specific connotations of feminine beauty as denotative meanings that demonise female sexuality (Barthes "Myth Today" 11-14).

There is a pragmatic reason for reading the poem as the interior monologue of a spectator who is positioned in front of the canvas, exactly where we stand when looking at the painted woman. The poem is inscribed onto the frame of the painting. Thus, Rossetti has not only included the semiotic differences between the two artistic media he uses: he has also assigned a semantic function to this frame. It establishes a causal relation between his two Lilith representations. The speaker's words frame the painted woman as Lilith. The painting is completed by 
interpretation, and, as we shall see, the text controls the understanding-or, to be more precise, the misunderstanding - of the painting. Thus, the type of intertextuality we are dealing with here is anagrammatical: Rossetti adopts a communicative situation from an established poetic tradition-ekphrasis-and uses this tradition as a foil for a later text.

In my reading, the poem's descriptions of the painted woman and the judgements passed on her are the mental creation of the beholder (the drama, after all, is in the sonnet, not in the painting). His ideas are the frame limiting his view. Yet this speaker-observer is not a voyeur spying on a lady making her toilette. When he begins his reflections on this portrait of a woman, he is positioned in front of the canvas, exactly where we are when looking at her:

Of Adam's first wife, Lilith, it is told, (The witch he loved before the gift of Eve,)

That, ere the snake's, her sweet tongue could deceive, And her enchanted hair was the first gold. (1-4)

The first line of the sonnet variation already requires particular attention: "Of Adam's first wife, Lilith, it is told"-the phrase "it is told" illustrates that the viewer is repeating time-honoured knowledge, retelling an old story. So, an externally imposed idea of female sexual allure affects his perception and superimposes itself on the image of a loosely-dressed lady absorbed in examining herself in a hand mirror. This woman, who in the picture does nothing more than personify physical beauty, is transformed into the Judeo-Christian figure of Adam's notorious first lover as we know her from the two key Judaic intertexts, the Alphabet of Ben Sira and the Zohar, as well as from the Apocrypha. In those sources, Lilith refuses sexual subjugation and demands equality with Adam. She is punished by God for deserting her husband and turns into a demoness who consumes men, thus embodying the destructive aspects of female sexuality. The traditional Lilith propaganda is at work in Rossetti's sonnet and, what is most important, from the very first line its operative presence is evident.

This propaganda and its sources are specified in the subsequent parenthetical insertion. The woman in the painting who -it must be stressed again-does nothing more than personify physical beauty, is immediately transformed into "Adam's first wife" and Eve's precursor. What is completely disregarded by the speaker, as it would detract from his vilification of Lilith, is that Eve did not turn out to be a "gift" either but likewise proved to be a false promise (at least from the male point of view).

The spectator and interpreter of body's beauty next elaborates on the nature of and reasons for Lilith's crime against patriarchal rule. The sonnet's octet is resonant with ahistoric characterisations and with easily understandable cultural codes of destructive femininity: the snake and spider $(3,7)$, animalistic images of female 
sexuality; "enchanted golden hair" (4), a symbol of beauty and a means of entrapment; eternal youth and a timeless magnetism (5), which dehumanise Lilith as much as her self-contemplation and indifference; and the weaving of a net which becomes a snare in her attempts at male mass murder. "[S]ubtly of herself contemplative," she "Draws men to watch the bright net she can weave, / Till heart and body and life are in its hold" (6-8). Her plan of attack is very much characteristic of a femme fatale. While attracting men who unfortunately are within the radius of visual attention-here again is the topos of concupiscentia oculorum, the lust of the eyes-she remains coolly aloof, "of herself contemplative," narcissistic to the point of complete indifference to her future clientele. Bullen perceptively remarks that her "threat to masculinity is not so much brought about by active aggression . . . as by passive self-absorption" (139). I shall return to this self-sufficiency and its central role in Rossetti's dual portrayal.

Thus established gender stereotypes evoking the fatal woman are projected onto the painting. Those stereotypes stem from two semantic fields, from the religious (the traditional Christian denunciation of the body) as well as the mythological (such as the Alphabet of Ben Sira), and they direct attention to the two literary contexts in which Lilith is present as the prototype of an alluring but treacherous she-devil. By means of the clichés enumerated in Rossetti's poem, the beautifulwoman in his painting is transformed into a fatal woman who ensnares "heart and body and life" (8).

The painting features what feminist critics have dubbed the schematised, "fragmented body"-an analytical category which has become essential to an investigation of the representation of women in art and literature (Cherry and Pollock 492; Pearce). That is to say, an exaggerated selection of colour-coded physical details such as bared curves, ruby lips or luxuriant tresses, all of which are conventionalised as connoting the wanton. The speaker's monologue then supplies a sequence of stereotypical allusions that cast over the physical attributes of the woman before us the long shadow of the Christian denunciation of bodily beauty and displays of sexuality.

The male viewer's mental portrayal of female beauty is continued in the sestet, where we find a final symbol of the femme fatale. We are told that "the rose and poppy are her flowers" (9), and will probably think at once of the dialectic of passion and poison implied by this pairing. The traditional associations of the colour red with lust and passion are emphatically present here, as well as the poppy's use as a drug, an overdose of which might easily kill (opium produces a state of euphoria, but also hallucinations, nightmares and delusions). Interestingly, however, most of the roses in Rossetti's painting are white. The white rose is ascribed to the Virgin Mary; it is a heavenly flower symbolising spiritual love, innocence, virginity and purity. The speaker-spectator of the sonnet makes no reference to the colour of the roses he sees, thus passing over an ambiguity that might qualify his fantasy of sexual danger. Similarly, Rossetti makes use of the polysemy of poppies to call attention to the 
speaker's one-sided interpretation. Poppy contains alkaloids which in antiquity were used as a sedative for the sick and as an anodyne for pain; opium was likewise the chief ingredient of laudanum, commonly used as a medicine in the nineteenth century to induce convalescence by sleep (Zacharias 175). Therefore, the floral imagery in the sonnet significantly adds to Lilith's colouring as an example of disastrous female sexuality, attractive and lethal.[2] The poem connotes an iconic representation of feminine beauty as fatal. With the help of these connotations, the implied speaker reinterprets a sexualised woman into a siren. He tries to turn his connotations into denotations of fatal femininity, in a reaffirmation of symbolic cultural codes of fatal womanhood.

We find a third semantic field in the penultimate tercet of the sonnet. Sensory images of "scent" (9), "soft-shed kisses" and "soft sleep" (10) introduce the realm of dreams and indicate the trance-like fascination of Lilith's victims. Again, the denunciatory Lilith mythology is at work in the speaker's understanding of the painting. This is continued in the last lines with his interpretation of the relations between men and women as battle in which the fatal woman is victorious-and again, none of his associations are visible in the painting. A woman's sexuality inevitably develops into a "net" (7), a "snare" (11), a spear-like "spell" (13) impaling those unfortunate enough to have responded to it. In an image of female triumph, Lilith leaves the youth's "straight neck bent, / And round his heart one strangling golden hair" (13-14). The contradictory text-image relations here reveal the sonnet to be the fantasy of a speaker-spectator.

If we turn to address the crucial question of the speaker's psychological position, and to ask why his imagination is so marked by the notion of fatal femininity that he should project it onto the picture, we shall need to refer to the findings of feminist literary criticism. Feminist critics first pointed out the concept of Lilith as the archetype of an independent, self-confident woman who was turned into a beautiful but evil nymphomaniac. As Ussher, who may be taken as representative of the feminist view here, succinctly puts it: "She is a witch . . . because she is powerful and strong" (Ussher 96; italics in original). In the interior monologue of Rossetti's sonnet, the most important poetic device is the ekphrastic construction of the speaker's point of view. Lilith's autonomous role in legend is essential to understanding his psychology. The attractiveness of the pictured woman makes him think of the beauty of the first woman. This association then prompts a second one, this time fully embedded in the malignant Lilith mythology. Such beauty in a woman is a weapon; such a woman signifies refusal of male control. This triggers his prejudiced notions of perilous female sexuality. It is the terror of the imagination that is most dangerous here. It turns the denotations of the image, an aesthetic representation of body's beauty, into the connotations of the poem-the symbolic interpretation of the painted woman as Lilith. As a consequence, we are even less likely to agree with Golden's contention that Rossetti's "sonnets give a portion of the history behind the principle figure on canvas" (396). It is not the history of the painted 
woman that is given, but an insight into the forces which shaped the speakerspectator's psycho-sexual history.

In addition, throughout the sonnet the speaker-spectator is entertaining the fantasy of not being victimised by the femme fatale he visualises. There is a multiplication of male victims from the singular "Adam" (1), the ancestral injured party, to the plural "men" in line 7 (the "he" in line 10 is also implicitly plural); a single "youth" is mentioned in line 12. The speaker excludes himself from this procession of victims. But with a closer look, his words turn self-subversive from line 10 onwards, and the carefully constructed façade of himself as a neutral observer collapses:

And still she sits, young while the earth is old,

And, subtly of herself contemplative,

Draws men to watch the bright net she can weave,

Till heart and body and life are in its hold.

The rose and poppy are her flowers; for where

Is he not found, $O$ Lilith, whom shed scent

And soft-shed kisses and soft sleep shall snare?

The direct address "O Lilith" (10) betrays the speaker's growing emotional involvement; and the shift to the present tense at "And still she sits" (5) marks the mental transfer he undertakes from a past story to the picture that is present before him. His rhetorical question "where / Is he not found, O Lilith", and the emotional exclamation "Lo!" (12), not only make clear that the painted beauty has been converted into the Lilith beast; they also betray that the painting has struck a personal chord with him. The implicit psychological undercurrent of his argument is as follows: other men could not resist and were victimised, and only I am exempt from their fate. By expressing his alleged detachment in the third-person narrative, he resists any identification with those male trophies but at the same time grants an insight into his own mind. This sunny assessment of his secure and distanced position is revealed as self-deceit. Rossetti's double work of art is therefore based on a striking psychological twist-which becomes evident only when taking into account the semantic clash between its visual and verbal parts, the picture and the poem. The beholder of body's beauty does not realise that he has fallen prey to sexual clichés that govern and influence his perception. The sonnet provides an interpretation of the painting and at the same time undermines this interpretation by deflating it from within.

At this stage, we should briefly note the formal clues Rossetti provides. His poem on Lilith is a conscious engagement with the form and content of the Italian sonnet-an engagement which would become particularly evident in the 1881 title "Body's Beauty." The new title emphasises the tension between the text's heading and the traditional expectations associated with the Italian form of the sonnet. This tensionbetween the sublimation and repression or re-channelling of sexual drives advocated by this type of sonnet, and the thoughts of Rossetti's speaker-persona 
repainting the woman he sees in the picture-constitutes an isotopic clash. It is this clash which provides the key to the interpreter's mindset. Rossetti's text is an outlet for a man's repressed sexual fantasies: "the 'woman' we see frozen in the masculine gaze is a creature consumed (and controlled) by sex" (Ussher 4). The male art observer whose musings we share is a priori unable to perceive, accept and enjoy visual erotic temptations.

A question remains. Why does the speaker detect danger where there is none? Why, when his mind overrides his eyes and blocks out the inconspicuous nature of the painted beauty, does he pick Lilith as the corpus delectans (the pleasure-giving body) mutating into the corpus delicti (the proof of the speaker's interpretation)? The blast from the past with which the sonnet opens-Lilith as the first and major symbol of disruptive female sexual autonomy-is an obvious choice for maligning a woman's physicality and sexuality. But there is more to Lilith's role and function. In a frequently quoted passage from a letter to his friend Dr. Thomas Gordon Hake, dated April 21, 1870, Rossetti writes:

You ask me about Lilith-I suppose referring to the picture-sonnet. The picture is called Lady Lilith by rights . . . and represents a Modern Lilith combing out her abundant golden hair and gazing on herself in the glass with that selfabsorption by whose strange fascination such natures draw others within their own circle. The idea which you indicate (viz: of the perilous principle in the world being female from the first) is about the most essential notion of the sonnet (Dante Gabriel Rossetti Letters 850; italics original).

While a surface reading of this passage corroborates the traditional femme fatale interpretation of Rossetti's two Liliths, a closer look supports our contention that the speaker of the sonnet succumbs in imagination to the Lilith mythology while contemplating the painting. In pointing out that only the poem features a fatal woman, Rossetti makes a clear distinction between it and-as Swinburne had already emphasised - the much more harmless picture. In addition, the passage also throws light onto the causes of the speaker's self-deception.

Rossetti himself draws attention to the contemporary significance of his Lady Lilith. The self-sufficiency of the painted woman "subtly of herself contemplative" is given a very specific point of reference: she is "a Modern Lilith" haunting the male mind. This brings us back again to feminist interpretations. Feminist literary critics have claimed that by endowing his Lilith with personality traits-such as self-absorption-that have little to do with her identity as it is known from ancient source texts, Rossetti was the first to make possible a reading of her as a feminist heroine and as the figurehead of the Women's Liberation Movement. Judith Plaskow's gives a synoptic description of feminist appropriations of Lilith, and Bram Dijkstra offers a good example of such a reading: "Lilith, who, in her unwillingness to play second fiddle to Adam, was, as Rossetti's work already indicated, widely regarded as the world's first virago" (Plaskow; Dijkstra 309). Similarly, Allen argues that Rossetti's portrayal of Lilith as 
an independent woman equates her, in her aspect as destroyer of men, with the New Woman of the 1860s-an equation expressing common male fears as the Women's Movement gained momentum:

Rossetti's Lady Lilith is, in the long run, alluring as well as dangerous, a Victorian sex-object who incorporated in her being the whole weight of fear and desire that Victorian gentlemen felt in confrontation with a woman's demand for independence. ("Strangling Golden Hair" 292-93)

These feminist interpretations support the reading I have proposed. The speakerspectator of Rossetti's sonnet performs mental gymnastics when faced with a woman whose self-interest brings to mind both the insurgency of Lilith and that of the Women's Liberation Movement. The painting's iconicity cannot counteract male fears. Bullen summarises: "Lady Lilith's self-contained indifference offers an unanswerable challenge to the male psyche" (Bullen 147-48). Rossetti's double Lilith then is a clear critique of the discriminatory, moralising ideology of the destructive, demonic woman and of its potential roots. The picture has an independent and equally strong meaning contrasting with the poem's statement-a meaning that is eradicated in the mind of the onlooker. It is his flow of sexual anxieties which projects biased associations onto the painting, and those associations are deconstructed as prejudiced and irrational.

Rossetti's double Lilith, then, is a clear critique of the discriminatory, moralising ideology of the destructive, demonic woman, and of its roots. The picture has an independent and equally strong meaning that contrasts with the poem's statementa meaning that is eradicated in the mind of Rossetti's spectator. His flow of sexual anxieties projects biased associations onto the painting, and those associations are deconstructed as prejudiced and irrational.

In conclusion, in its emphasis on the contradictory relations between image and text, my argument diverges from traditional feminist readings. The two Liliths become a critical comment on what in the twentieth century has been labelled spectatorship theory-in particular John Berger's "surveyed female" (47) and Laura Mulvey's concept of the patriarchal gaze in art. Rossetti's portrayals of Lilith make explicit a biased response to images of women. They also demonstrate that meaning does not reside within images but is constructed at the moment of consumption. Seen in this light, Rossetti's poem shows how feminist criticism can occasionally contain its own backlash. Rossetti was accused of wallowing in "the pleasure to produce and reproduce patriarchal relations" (Cherry and Pollock 494). In this case, however, what was claimed as a prime example of poetic and artistic misogyny in fact preempts those feminists who accuse Rossetti of trumpeting the objectification of women and of supporting the chauvinist mechanics of women's sexual exploitation. Thus, the whole heated feminist discussion about male voyeurism in art becomes irrelevant here. The poem explicitly turns a canvas into a surface for the projection of male interpretations and shows that beauty indeed lies in the eye and mind of the 
beholder. A man's misguided idea of women is criticised here. And Dante Gabriel Rossetti, as a Victorian ancestor of twentieth-century images-of-women, proves to be far ahead of the feminists.

\section{Works Cited}

Ainsworth, Maryann Wynn. Dante Gabriel Rossetti and the Double Work of Art. New Haven: Yale University Press, 1976.

Allen, Virginia M. The Femme Fatale: Erotic Icon. New York: Whitston, 1983.

---. "'One Strangling Golden Hair': Dante Gabriel Rossetti's Lady Lilith." Art Bulletin 14 (1984): 285-94.

Barthes, Roland. "Myth Today." Cultural Theory and Popular Culture: A Reader. Ed. John Storey. 2nd ed. Hemel Hempstead: Prentice Hall, 1998: 110-117.

Berger, John. Ways of Seeing. London: BBC Series, 1972.

Bullen, J. B. The Pre-Raphaelite Body: Fear and Desire in Painting, Poetry and Criticism. Oxford: Clarendon Press, 1998.

Cherry, Deborah, and Griselda Pollock. "Patriarchal Power and the PreRaphaelites." Art History 7 (1984): 480-94.

Dijkstra, Bram. Idols of Perversity: Fantasies of Feminine Evil in Fin-de-Siècle Culture. Oxford: OUP, 1986.

Golden, Catherine. "Dante Gabriel Rossetti's Two-Sided Art." Victorian Poetry 26 (1988): 395-402.

Greimas, A.J. Strukturale Semantik. Braunschweig: Vieweg, 1971.

Johnston, Robert. Dante Gabriel Rossetti. New York: Twayne, 1969.

Miller, John Raymond. Dante Gabriel Rossetti from the Grotesque to the Fin de Siècle: Sources, Characteristics and Influences of the Femme Fatale. Ann Arbor: Harper, 1974.

Mulvey, Laura. Visual and Other Pleasures. Basingstoke: Macmillan, 1989.

Nead, Linda. "Woman as Temptress: The Siren and the Mermaid in Victorian Painting." Leeds Art Calendar 91 (1982). 34-47.

Pearce, Lynne. Image-Woman-Text: Readings in Pre-Raphaelite Art and Literature. New York: Harvester Wheatsheaf, 1991. 
Plaskow, Judith. "The Coming of Lilith: Toward a Feminist Theology." Carol P. Christ and Judith Plaskow, eds., Womanspirit Rising: A Feminist Reader in Religion. New York: Harper, 1979. 198-209.

Rossetti, Dante Gabriel. Letters of Dante Gabriel Rossetti. Ed. Oswald Doughty and John Robert Wahl. 4 vols. Oxford: Clarendon Press, 1965.

---. Dante Gabriel Rossetti: Poems and Translations 1850-1870. 6th ed. Oxford: OUP, 1968.

Rossetti, William. Some Reminiscences. London: Routledge, 1906.

Swinburne, Algernon Charles. "Notes on Some Pictures of 1868." The Complete Works of Algernon Charles Swinburne: Poetical Works. Ed. Sir Edmund Gosse and Thomas James Wise. Vol. 5. New York: Russell \& Russell, 1968. 196-216.

Ussher, Jane M. Fantasies of Femininity: Reframing the Boundaries of Sex. London: Penguin, 1997.

Zacharias, Irmgard. Die Sprache der Blumen. Rosenheim: Trierer Buchverlag, 1982.

[1] All subsequent quotations from "Lilith" will be given by line number, in parentheses in the text.

[2] Rossetti adds a third flower in his painting, the foxglove - a flower which is not mentioned in the sonnet. It is placed in the rear of the composition, in front of two candles flanking a mirror. The foxglove produces digitalin, which, similar to laudanum and opium, is both a medicine and a poison. In contrast to the other flowers whose ambiguity is dissolved and rendered positive in the picture, the foxglove's double-edged symbolism remains unchallenged; it is thus the only detail supporting the speaker-spectator's flight of fancy.

[3] It should be emphasised that Rossetti was not in favour of female agitation over the "woman question," which evoked clamorous argument in London during the 1860s. For instance, he cautioned his sister Christina against the feminist movement and dubbed it the "Shrieking Sisterhood" (William Rossetti, Reminiscences 227). Allen gives a detailed summary of Rossetti's opposition to the feminist movement ("'Strangling Golden Hair"' 293).

[4] This assessment is one of a number of relatively recent feminist readings which address the question of voyeurism. Rossetti's depiction of Lilith as a narcissist has inaugurated a discussion that regards both the painting and the poem as 
problematising the nature of masculine desire, by raising questions about the traditional relationship between the male as subject and the female as object. Lilith's self-centredness is said to constitute a statement about masculine desire and fear. By refusing compliance with the controlling male gaze and looking instead at herself in a mirror, the painted woman turns men into objects desiring her, thus subjecting them to her powers and "threaten[ing] the identity of the male voyeur" (Bullen 148. See also Cherry and Pollock 492; Ussher 17; Nead). As my analysis has uncovered, the nature of male desire and fear are indeed problematised by Rossetti's representations, though in quite a different respect which recent feminist criticism has failed to recognise. Rossetti refashions destructive images of female sexuality by exposing them as the products of the repressed desires and narrow-minded fears generated by patriarchal gender ideology. 